\title{
Заметка академика В.И. Вернадского об изучении и практическом использовании шунгита из окрестностей Онежского озера
}

\section{Янин Е.П.}

Институт геохимии и аналитической химии им. В.И. Вернадского РАН, Москва, yanin@geokhi.ru

\begin{abstract}
Аннотация. В статье приводится забытая заметка В.И. Вернадского, посвященная вопросам изучения и практического использования шунгита из окрестностей Онежского озера. В заметке излагаются представления Вернадского о происхождении, важнейших свойствах и необходимых направлениях изучения шунгита. Рассматривается также канва событий, способствовавших ее появлению.

Ключевые слова: В.И. Вернадский, архивное наследие, шунгит, аморфный углерод, ванадий, Онежское озеро.
\end{abstract}

\section{Note by Academician V.I. Vernadsky about the study and practical use of shungite from the vicinity of Lake Onega}

\author{
Yanin E.P. \\ Vernadsky Institute of Geochemistry and Analytical Chemistry of Russian Academy of Sciences, Moscow, \\ yanin@geokhi.ru
}

\begin{abstract}
The article contains a forgotten note by V.I. Vernadsky, dedicated to the study and practical use of shungite from the vicinity of Lake Onega. The note sets out Vernadsky's ideas about the origin, the most important properties and the necessary directions for the study of shungite. The outline of the events that contributed to its appearance is also considered.
\end{abstract}

Key words: V.I. Vernadsky, archival heritage, shungite, amorphous carbon, vanadium, Lake Onega.

В архиве РАН сохранилась небольшая заметка академика В.И. Вернадского (автограф с незначительными авторскими вставками и исправлениями), посвященная проблемам изучения и практического использования шунгита из окрестностей Онежского озера (Архив РАН. Ф. 518. Оп. 1. Д. 103. Л. 1-2). Она, по мнению автора этих строк, представляет интерес не только для исследователей научного творчества нашего великого соотечественника, но для специалистов-«шунгитоведов». Записка полностью публикуется ниже:

«В Ленинградской области в окру́ге Онежского озера находятся залежи шунгита, заслуживающие серьезного внимания. Нам необходимо напрячь все силы для научно точного и ясного быстрого выявление всех источников энергии, какие в области находятся. Одним из таких источников является шунгит. К сожалению, шунгит недостаточно и крайне неполно исследован; в полной мере мы не можем сейчас сказать, что именно он может дать, как нужно его использовать.

Это прежде всего надо выяснить и это можно сделать только одним путем - количественным точным научным исследованием.

В достаточно мощных лаборатория это может быть сделано быстро.

Прежде чем перейти к тому, что надо выяснить - несколько слов о шунгите.

Шунгит прежде принимали за антрацит, богатый свободным углеродом каменный уголь.

Это оказалось неверным. Шунгит - одна из форм самородного углерода, ни с чем не соединенного. Можно различить три семейства самородного углерода, отличающихся резко различным соединением атомов этого элемента: семейство алмаза и семейство графита, разделяющееся на два подсемейства - 1) кристаллического графита и 2) дисперсного шунгита.

В то самое время, как распределение атомов углерода в алмазе и в графите нам ясно и точно известно - их распределение в дисперсных углеродах или самородных смесях, к числу которых принадлежит шунгит, нам неизвестно - таких углеродов есть несколько и их строение различное. Для шунгита оно не изучено, и эта неизученность привела к тому, что при практическом использовании не различали два разных тела, находящихся вместе - черный блестящий, металлического вида 
шунгит собственно (так названный профессором А.А. Иностранцевым, первым обратившим на него внимание) и матовый серый «графититовый уголь». Этот последний преобладает и может быть добыт, по-видимому, в большом количестве.

На что может быть употреблен шунгит и графититовый уголь?

Последний, как все каменные угли, может идти на топливо. Его пробовали - неудачно - употреблять как антрацит. Антрацит тоже содержит некоторое количество аморфного углерода - но свойства олонецкого графититового угля оказались иными. Вероятно, аморфный углерод в них разный. Между тем, близкие к нему «полуантрациты» («графитовые угли») Америки (Род-Айленд, Массачусетс) давно являются в технике практически важными телами. Надо использовать американский опыт. Но олонецкий графититовый уголь своеобразен, и перед исследованием его на топливо надо обратить внимание на его битуминозность, как и для антрацита и дисперсных углей («графититовый уголь» Олонецкого края ближе к битуминозным углям, чем к каменным углям).

Недавние анализы выяснили, что и шунгит и графититовый уголь содержат ванадий в таком количестве (шунгит больше), что могут служить для добычи этого важного металла.

Но уже это недавнее неожиданное открытие показывает, что прежде надо точнее изучить шунгит, дабы не потерять, по неведению, то, что он может дать при разумном с ним обращении.

Для этой цели необходимо: 1) изучить его рентгенограмму, 2) его металлические свойства, которые могут получить применение в электротехнике и 3) его радиоактивность. Одна из форм аморфного углерода (кольм в Скандинавии) содержит уран и радий и служила рудой на эти металлы. Радиоактивность шунгита, насколько знаю, не изучалась. Это свойство шунгита (и графититового угля) может быть выяснено в Государственном Радиевом институте, если туда будут доставлены образцы: 1) шунгита (разного виды), 2) графититового угля и 3) их зола. Проба может быть сделана на уран, торий и радий.

Но прежде всего необходимо произвести точную геологическую разведку. Много для выяснения месторождений дали работы профессора Тимофеева - но надо поставить дело на практическую почву. Идти по шаблону здесь нельзя: его здесь нет. Другого месторождения шунгита нигде пока не найдено. Надо, чтобы разведку вел образованный и вдумчивый геолог».

Дату составления заметки Вернадский не указал, что для него совершенно не свойственно. Не указано также мероприятие (или издание), для которого она готовилась. Очевидно, что заметка составлялась им в некоторой спешке, так сказать, для памяти, поскольку по своему содержанию и структуре изложения текста она скорее напоминает тезисы выступления. Из контекста можно предположить, что записка подготовлена Вернадским в конце 1931 г. или в начале 1932 г. Это предположение подтверждается и канвой событий, характерных для указанного периода времени и которые позволяют установить вероятное мероприятие, на котором планировал выступить Вернадский.

Так, 1931-1932 гг. были в СССР временем пристального внимания к проблеме практического использования карельского шунгита. Например, в Генеральном плане электрофикации СССР для Ленинградской области и Автономной Карельской ССР (АКССР) отмечалось, что для этих регионов большой интерес представляет шунгит северных берегов Онежского озера, который при медленном горении дает температуру в $900{ }^{\circ}$ и от 17 до 40 \% золы, содержащей промышленные доли графита, ванадия, титана, меди и никеля (Шателен, Ден, 1932). В апреле 1931 г. Оргбюро по созыву 1-го Энергетического съезда Ленинградской области и АКССР ставит вопрос о необходимости изучения теплотехнических и химических свойств шунгита (Бюллетень.., 1931). На IV-м Объединенном пленуме Карельского Областного комитета и Областной контрольной комиссии ВКП(б) (20-23 октября 1931 г.) было принято решение о необходимости организации технологического и химического исследования шунгита как топлива и о возможности использования содержащегося в шунгитовой золе ванадия (Решения IV-го объединенного.., 1931). XI-я Карельская областная конференция ВКП(б), состоявшаяся 15-20 января 1932 г., обратилась к Ленинградскому обкому ВКП(б) с просьбой всемерно помочь Карелии научными силами в деле освоения сырьевых и энергетических ресурсов АКССР, особенно «по линии использования шунгитов» (Резолюции и постановления..., 1932). На XVII конференции ВКП(б), состоявшейся 30 января - 4 февраля 1932 г., ставится вопрос о не- 
обходимости использования шунгита в качестве топлива в Ленинградской области и о разработке шунгитов для получения ванадия (XVII конференция..., 1932). В мае 1932 г. начал свою деятельность трест «Шунгит» («Государственный трест по добыче и переработке карельских шунгитов, сланцев и редких элементов»), созданный решением Совнаркома КАССР от 4 апреля 1932 г. (Чернышев, 1932). В конце 1932 г. в Петрозаводске состоялась 1-я Карельская геологоразведочная конференция, на которой шунгитовая тематика нашла широкое отражение (Труды 1-й..., 1933). Интерес к шунгиту в это время был настолько велик, что нашел отражение в художественной литератуpe (см., например, Норин, 1932).

С точки зрения датирования публикуемой заметки Вернадского, значение имеют следующие факты. Так, в 1931-1932 гг. первый секретарь Ленинградского обкома партии С.М. Киров привлек целый ряд научных учреждений к решению вопросов о пригодности шунгита как топлива и использовании содержащей ванадий шунгитовой золы (Геологические исследования.., 1936). По его инициативе 9 июня 1931 г. был создан Комитет содействия экономическому и культурному развитию Мурманского округа и Карелии при исполнительном комитете Ленинградского областного совета рабочих, крестьянских и красноармейских депутатов (Карело-Мурманский комитет), председателем которого стал И.Ф. Кадацкий (тогда - председатель Исполнительного комитета Ленинградского областного Совета). В состав Комитета вошли партийные и хозяйственные работники Ленинграда, Карелии, Мурманска и Хибин, а также такие известные ученые, как В.И. Вернадский, А.Е. Ферсман, И.М. Губкин, А.А. Байков, Г.О. Графтио, геологи В.И. Влодавец, А.Н. Лабунцов (Пятковский, 1964). На его заседания и пленумы приглашались специалисты разного профиля и руководителя разного уровня. В частности, пленум Комитета (20 февраля 1932 г.) подвел итоги работ по определению запасов шунгита, использованию его как топлива и химического сырья (Борисов, 1932). По сведениям (Мочалов, 1982), Вернадский состоял членом Комитета вплоть до его ликвидации 25 ноября 1935 г. Между прочим, Вернадский, оценивая Кирова (как руководителя и хозяйственного деятеля), отметил, что он - «несомненно крупный и хороший человек. Я лично почти с ним не сталкивался» (Вернадский, 2001, с. 378). Может быть, фраза «почти не сталкивался» указывает на возможную встречу Вернадского с Кировым на одном из заседаний Карело-Мурманского комитета? В 1931 г. (25-30 ноября) в Ленинграде состоялась 2-я выездная чрезвычайная сессия АН СССР, посвященная производственным ресурсам и перспективам развития производительных сил Ленинградской области. Вернадский принимал участие в ее работе (Корель, 1931). На Общем заседании Ферсман представил доклад, посвященный ископаемому сырью Ленинградской области, в котором шунгит лишь указывается как ископаемое областного значения, которое пока не эксплуатируется (Ферсман, 1932). Вернадский, сообщая в своей заметке о «недавних анализах», которые выявили высокие количества ванадия в шунгите, явно имеет в виду исследования В.И. Крыжановского. Как известно, Крыжановский - «ревностный ученик и последователь В.И. Вернадского» (Варганов, 1949, с. 10) - исследовал месторождение Шуньга осенью 1928 г. (Годовиков, 1989) и в золе шунгита обнаружил значительные количества окиси ванадия (Крыжановский, 1931). Показательно, что указанная статья Крыжановского была анонсирована в Отчете о деятельности АН СССР за 1930 г. (Отчет о.., 1931). В записке Вернадский упоминает работу В.М. Тимофеева (Тимофеев, 1924) и указывает на необходимость произвести геологическую разведку залежей шунгита с привлечением для этих целей «образованного и вдумчивого геолога». Как известно, в 1932 г. Тимофеев приступил к руководству разведками шунгитовьх месторождений Заонежья (Проф. В.М. Тимофеев.., 1936). Вернадский также ставит вопрос о необходимости изучения радиоактивность шунгита и указывает, что это может быть сделано в Радиевом институте. Показательна запись в дневнике ученого (6 марта 1932 г.): «Был в Минералогическом кабинете (в Минералогическом институте - Е.Я.), взял образцы шунгита, графита» (Вернадский, 2001, с. 271). Не исключено, что именно эти образцы были предназначены для исследований в Радиевом институте. Приведенные выше сведения позволяют достаточно уверенно предположить, что записка Вернадского была подготовлена им либо в ноябре 1931 г. (например, для участия в прениях во время 2-й выездной чрезвычайной сессии АН СССР), либо готовилась для выступления на заседаниях и пленумах Карело-Мурманского комитета (вторая половина 1931 г. - январь-февраль 1932 г.). 
В заключение отметим, что в 1899 г. Вернадский впервые суммирует свои соображения о природе и происхождении шунгита (Вернадский, 1899). В классе самородных элементов он выделяет подгруппу углерода, включив в нее графит и близкие к нему тела, а все графиты подразделяет на несколько разностей, из которых «наиболее достоверны: 1) графит и 2) графитит или шунгит» (там же, с. 106), причем от графита вторая разность (называет ее аморфной разностью углерода) «отличается отсутствием ясного кристаллического сложения, как будто меньшим удельным весом < ..> и иным отношением к действию сильных окислителей. <...> Она черного цвета, так же мягка как графит. Встречается обыкновенно в компактных сплошных массах или в тонкой пыли, рассеянной в другой породе. При сильном нагревании (а в природе - при давлении) переходит в графит. Наиболее ясно образование ее на земной поверхности из углеродистых соединений. Медленно изменяясь вековым процессом разные соединения углерода мало по малу теряют водород, кислород, азот и т. п. элементы, и дают самородный углерод. Так образуется графитит, являясь окончательным продуктом изменения каменного угля» (там же, с. 109). Как известно, название «графитит» («Graphitite») было использовано W. Luzi (1891) для обозначения плотных разностей графита, не дающих вспучивания с азотной кислотой. Вернадский считает, что графитит состоит из графита, тесно смешанного с аморфным углеродом (шунгитом) или какими-то органическим соединениями. В 1912 г Вернадский отметит, что в семействе графита можно различать по крайней мере две разности: 1) графит и 2) шунгит (так называемый аморфный уголь). Он указывает, что название шунгит будет употреблять «для обозначения природного аморфного углерода» (Вернадский, 1912, с. 529). По химическому составу шунгит представляет переход к антрацитам и является промежуточным продуктом при превращении каменного угля в графитит и в конце концов в графит. «Шунгит, или аморфный углерод, образуется в природе как продукт распадения органических веществ. Обыкновенно он находится рассеянным в ничтожных пылинках в древних осадочных породах, но иногда скопляется в значительных массах, когда образуется из мощных отложений углеродистых тел» (там же, с. 556). В качестве такого «скопления» Вернадский приводит район Шуньги, где шунгит «залегает в древних метаморфизированных докембрийских породах, образуя пропластки среди глинистых сланцев, мощностью до 2 м, в сопровождении кварца, пирита и т. д.» и «является промежуточным продуктом при превращении каменного угля в графитит и в конце концов в графит» (Вернадский, 1912, с. 556). В 1927 г. среди минералов самородного углерода в семействе мягких разностей углерода (графита) он выделяет два подсемейства: 1) явно кристаллические графиты - графит собственно и графитит и 2) дисперсные системы - шунгиты - природный уголь, шунгит, природный кокс (Вернадский, 1927), подчеркивает, что шунгиты должны быть отделены от полуантрацитов, а для дисперсных систем подсемейства шунгита с химической точки зрения мыслимы несколько разностей и предлагает различать «дисперсные системы, генетически связанные с битумами, богатые углеводородами (?). К ним надо относить, судя по данным В. Тимофеева (1924), шунгит» (Вернадский, 1927, с. 349).

Вернадский общался со многими учеными, профессионально занимавшихся проблемами шунгита, среди которых П.А. Борисов, М.Б. Едемский, В.И. Крыжановский, Н.А. Орлов, В.М. Тимофеев (в Архиве РАН отложились их письма к нему). Даже в конце 1930-х гг. Вернадский, научные интересы которого уже лежали в других областях геологии, по-прежнему оставался, говоря словами из письма к нему (16 мая 1937 г.) профессора Н.А. Смольянинова, «вдохновителем минералогической работы» для многих отечественных минералогов (Архив РАН. Ф. 518. Оп. 3. Д. 1524. Л. 1).

\section{Литература}

1. Борисов П. Шунгит // Карело-Мурманский край. 1932. № 1-2. С. 42-44.

2. Бюллетень Организационного бюро по созыву I Энергетического съезда Ленинградской области и АКССР. № 3. 12 апреля 1931 г. Л. Изд-во: Ленинградского областного отделения Всесоюзного энергетического комитета. 1931. 44 с.

3. Варганов Г.И. Жизнь и деятельность профессора Владимира Ильича Крыжановского (1881-1947) // Труды Минер. музея АН СССР. 1949. Вып. 1. С. 7-17.

4. Вернадский В.И. Лекции описательной минералогии. М. 1899. 288 с.

5. Вернадский В.И. Опыт описательной минералогии. Т. 1. Самородные элементы. Вып. 4. СПб. 1912. С. 497-656. 
6. Вернадский В.И. История минералов земной коры. Т. І. Вып. ІІ. Л. Изд-во: НХТИ НТУ ВСНХ. 1927. С. 209-376.

7. Вернадский В.И. Дневники: 1926-1934. М. Изд-во: Наука. 2001. 456 с.

8. Геологические исследования в Советской Карелии // Материалы по геологии и полезным ископаемым Карельской АССР. Сб. № 1 Ленинградского геологического треста. Л.-М. Изд-во: ОНТИ НКТП СССР. 1936. С. 3-9.

9. $\quad$ Годовиков А.А. Владимир Ильич Крыжановский // Очерки по истории геологических знаний. Вып. 25. М. Изд-во: Наука. 1989. С. 72-81.

10. Корель Ив. Исторические дни // Вестник Академии наук СССР. 1931. № 10. С. 9-20.

11. Крыжановский В.И. Геохимия месторождений шунгита // Минеральное сырье. ВИМС. М. 1931. № 10-11. С. 955-968.

12. Мочалов И.И. Владимир Иванович Вернадский. 1863-1945. М. Изд-во: Наука. 1982. 488 с.

13. Норин С. Шунгит (отрывок из повести) // Плечом к плечу. Сборник национальных секций Ленинградского комитета Союза советских писателей. Л. Изд-во: Ленгихл. 1932. С. 75-91.

14. Отчёт о деятельности Академии наук Союза Советских Социалистических Республик за 1930 г. Л. Изд-во: АН СССР. 1931. 278 с.

15. Проф. В.М. Тимофеев (его жизнь и деятельность) // Материалы по геологии и полезным ископаемым Карельской АССР. Сборник № 1 Ленинградского геологического треста. Л.-М. Изд-во: ОНТИ НКТП СССР. 1936. С. 9-14.

16. Пятковский В.П. Социалистическое преобразование Кольского полуострова в годы первой пятилетки: Автореф. дисс. ... канд. исторических наук. Л. 1964. 23 с.

17. Резолюции и постановления XI-ой Карельской областной конференции ВКП(б). Петрозаводск. Изд-во: Каробкома ВКП(б). 1932. 45 с.

18. Решения IV-го объединенного пленума Карельского Областного Комитета и Областной Контрольной Комиссии ВКП(б) (20-23 октября 1931 г.). Петрозаводск. Изд-во: Каробкома ВКП(б). 1931. 76 с.

19. XVII конференция Всесоюзной коммунистической партии (б). Стенографический отчет. М.: Партийное издательство. 1932. 296 с.

20. Тимофеев В.М. К генезису Прионежского шунгита // Труды Ленинградского общества естествоиспытателей. Отделение геологии и минералогии. 1924. Т. 39. Вып. 4. С. 99-122.

21. Труды 1-й Карельской геологоразведочной конференции. Л. 1933. 121 с.

22. Ферсман А.Е. Ископаемое сырье Ленинградской области и его перспективы. Л. Изд-во:АН СССР. 1932.38 с.

23. Шателен М.А., Ден Н.В. Электрофикация Ленинградской области и Автономной Карельской ССР // Генеральный план электрификации СССР. Т. 8. Ч. 1. Сводный план электрификации. М.-Л. Гос. соц.экон. изд-во. 1932. С. 171-240.

24. Чернышев А. Шунгит // Карело-Мурманский край. 1932. № 3-4. С. 30-31.

25. Luzi W. Zur Kenntniss des Graphitkohlenstoffes // Berichte der Deutschen Chemischen Gesellschaft. 1891. XXIV. № 19. S. 4085-4095. 